\title{
22. Türkçedeki bazı Batılı alıntıların kökenleri üzerine
}

\section{Berrin AKÇALI ${ }^{1}$}

APA: Akçalı, B. (2021). Türkçedeki bazı Batılı alıntıların kökenleri üzerine. RumeliDE Dil ve Edebiyat Araştırmaları Dergisi, (23), 339-348. DOI: 10.2900o/rumelide.949037.

\section{$\ddot{\mathbf{O} z}$}

Bu çalışmada kamping, kanyon, kargo, kateter, komodor, kompleks, konteyner ve kovboy sözcüklerinin köken tespiti ele alınmaktadır. Bundan dolayı öncelikle söz konusu sözcüklerle ilgili birtakım sözlüklerdeki yazılanlara bakılmış, köken verileri gözden geçirilmiştir. Ardından bu sözcüklerin çeşitli Türkçe sözlüklerde bulunan köken ve anlam bilgileri yazılmıştır. Köken konusunda verilen bilgilerde farklılıklar tespit edildiğinde ilgili yabancı sözlüklerdeki İngilizce ve Fransızca anlamları, çevirileri de yapılarak birlikte verilmiştir. Ayrıca bahsedilen sözcüklerin kaynak dildeki ve gerekli görülen yabancı dillerdeki telaffuz biçimleri gösterilmiş, bunlar Türkçedeki telaffuz biçimleriyle karşılaştırılmıştır. Bu sözcüklerin taranan sözlüklerde bulunup bulunmamalarına göre tarihî veriler elde edilmiştir. Türkçe ve İngilizce, Fransızca gibi yabancı kaynaklarda geçen tarihî verilerin yanı sıra anlam bilimsel ve ses bilimsel veriler de dikkate alınmıştır. Böylelikle kamping, kanyon, kargo, kateter, komodor, kompleks, konteyner ve kovboy sözcüklerinin Türkçeye hangi dillerden alıntılandıklarının doğru tespit edilmesi amaçlanmıştır. Bu çalışmada araştırılan kamping, kanyon, kargo, kateter, komodor, kompleks, konteyner ve kovboy sözcüklerinin kökenleri açısından bazen bazı Türkçe sözlüklerin aynı görüşte olup ortak noktada buluştukları, bazen de birbirinden farklı görüşler belirttikleri fark edilmiştir. Bundan dolayı adı geçen sözcüklerin kökenleri hakkındaki görüşlerimizin kimi zaman birtakım sözlüklerle aynı doğrultuda olduğu, kimi zaman da diğer bazı sözlüklerden farklı olduğu sonucuna ulaşılmıştır. Tarihî, anlam bilimsel ve ses bilimsel veriler sayesinde bunların nedenleri açıklanmıştır.

Anahtar kelimeler: Türk dili, köken bilimi, anlam bilimi, ses bilimi, Batı kökenli alıntılar

\section{On the origins of some loanwords of Western origin in Turkish}

\begin{abstract}
In this study, the origin determination of the words kamping, kanyon, kargo, kateter, komodor, kompleks, konteyner and kovboy is examined. For this reason, first of all, what is written in some dictionaries about the words in question was looked at, and their origin data were reviewed. Subsequently, the origins and meanings of these words in various Turkish dictionaries were written. When differences were observed in the information given about the origin, the English and French meanings in the relevant foreign dictionaries were also translated and given together. In addition, the pronunciation forms of the mentioned words in the source language and in foreign languages that were deemed necessary were shown, and these were compared with the pronunciation forms in Turkish. Historical data were obtained according to whether these words were found in the scanned dictionaries or not. In addition to historical data in Turkish and foreign sources such as English and French, semantic and phonological data were also taken into consideration. In this way, it is aimed to correctly detect from which languages the words kamping, kanyon, kargo, kateter, komodor,
\end{abstract}

Dr., (İstanbul, Türkiye), akbumin@gmail.com, ORCID ID: oooo-ooo3-3041-5648 [Araştırma makalesi, Makale kayıt tarihi: 31.03.2021-kabul tarihi: 20.06.2021; DOI: 10.29000/rumelide.949037]

Adres $\mid$ Address

RumeliDE Dil ve Edebiyat Araşttrmaları Dergisi $\quad$ RumeliDE Journal of Language and Literature Studies Osmanağa Mahallesi, Mürver Çiçeği Sokak, No:14/8 Osmanağa Mahallesi, Mürver Çiçeği Sokak, No:14/8

Kadıköy - İSTANBUL / TÜRKIYE 34714 Kadıköy - ISTANBUL / TURKEY 34714 e-posta: editor@rumelide.com

e-mail: editor@rumelide.com,

tel: +90 505 7958124, +90 2167730616 phone: +90 505 7958124, +90 2167730616 


\begin{abstract}
kompleks, konteyner and kovboy were loaned to Turkish. In terms of the origins of the words kamping, kanyon, kargo, kateter, komodor, kompleks, konteyner and kovboy, which were investigated in this study, it was noticed that sometimes some Turkish dictionaries agree and meet at a common point, and sometimes express different opinions from each other. Therefore, it has been concluded that our views about the origins of the words mentioned are sometimes in line with some dictionaries and sometimes different from some other dictionaries. Their reasons have been explained with the help of historical, semantic and phonological data.
\end{abstract}

Keywords: Turkish language, etymology, semantics, phonology, loanwords of western origin

\title{
Giriş
}

Sözlüklerde geçen bazı sözcüklerin kökenlerine yönelik veriler bakımından bazen tutarlı bazen de birbirine uymayan ifadelere rastlanabilmektedir. Bazı durumlarda da kimi sözcüklerin kökeni konusunda kesin bir bilgi verilememektedir. Alıntı sözcüklerin kökeninin tespit edilmesinde tarihî, anlam bilimsel ve ses bilimsel verileri göz önünde bulundurmak doğru sonuçlara ulaşabilmek açısından son derece önemlidir.

Bu çalışmanın konusu kamping, kanyon, kargo, kateter, komodor, kompleks, konteyner ve kovboy sözcüklerinin köken tespitidir. Sözlüklerdeki k harfinden önce gelen kelimeler daha önce başka bir makalede incelendiğinden burada bahsedilen bu sözcükler örnek olması açısından seçilmiştir. Bu çalışmayı ele almamızdaki sebep, bu sözcüklerin Türkçeye hangi dillerden geçtikleri konusunda birtakım sözlüklerin bazen ortak bir noktada birleşmediklerinin görülmesinden kaynaklanmaktadır. Mesela incelenen sözcüklerden kamping Türkçe Sözlük'te, Türkçenin Alntılar Sözlüğü’nde ve Türkçede Batı Kökenli Kelimeler Sözlüğ̈̈’nde Fransızca, Misalli Büyük Türkçe Sözlük’te ise İngilizce kökenli ya da kanyon sözcüğü 1944 basımlı Türkçe Sözlük’te İspanyolca, Türkçe Sözlük’te ve Türkçenin Alıntılar Sözlüğ̈̈nde Fransızca, Misalli Büyük Türkçe Sözlük ve Türkçede Batı Kökenli Kelimeler Sözlüğ̈̈’nde ise İngilizce kökenli olarak geçmektedir. Bundan dolayı bahsedilen sözcüklerin taranan sözlüklerdeki (Thesaurus Linguarum Orientalium Turcicae-Arabicae-Persicae: Lexicon Turcico-Arabico-Persicum, A Turkish and English Lexicon: shewing in English the significations of the Turkish terms, Kâmûs-ı Türkî, 1944 basımlı Türkçe Sözlük, Türkçe Sözlük, Misalli Büyük Türkçe Sözlük, Türkçenin Alıntılar Sözlüğü, Türkçede Batı Kökenli Kelimeler Sözlüğü) kökenleriyle alakalı verilen bilgileri karşılaştırılmıştır. Farklı ifadelerin yer alması hâlinde sağlam köken bilgilerine ulaşabilmek için tarihî, anlam bilimsel ve ses bilimsel veriler esas alınarak bu farklllıkların giderilmesine çalışılmıştır. Böylelikle adı geçen sözcüklerin Türkçeye hangi dillerden alıntılandıklarının doğru tespit edilmesi amaçlanmıştır. Bu amaç doğrultusunda kamping, kanyon, kargo, kateter, komodor, kompleks, konteyner ve kovboy sözcüklerinin ilgili Türkçe ve yabancı sözlüklerde geçen köken bilgilerini, anlamlarını ve telaffuzlarını karşılaştırarak gösterelim:

\section{Kamping sözcügüünün kökeni}

Kamping sözcügü Türkçe Sözlük’te (= TS), Türkçenin Alnntılar Sözlüğü’nde (=TAS) ve Türkçede Batı Kökenli Kelimeler Sözlüğ̈̈’nde (=TBKKS) 'Kamp kurma yeri' (TS, 2011: 1290; TAS, 2015: 410; TBKKS, 2015: 618), Misalli Büyük Türkçe Sözlük’te (=MS) 'Özellikle yaz günlerinden faydalanmak isteyenlerin konaklaması için ayrılmış yer' (MS, 2011: 1564) olarak tanımlanmıştır. Thesaurus Linguarum Orientalium Turcicae-Arabicae-Persicae: Lexicon Turcico-Arabico-Persicum'da (= Men.), A Turkish and English Lexicon'da (= Red.), Kâmûs-ı Türkî'de (= KT), 1944 basımlı Türkçe Sözlük'te (= TS 1944)

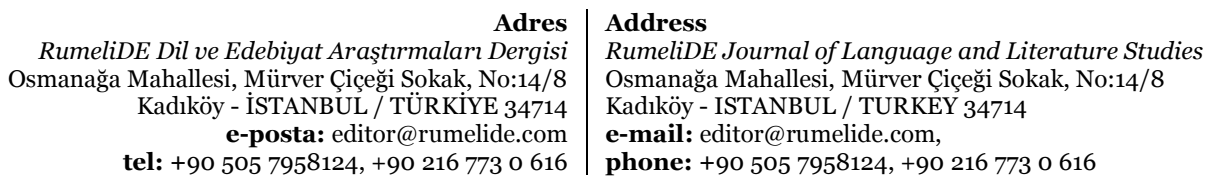


yoktur. TS, TAS ve TBKKS'de Fransızca, MS'de ise İngilizce kökenli olduğu yazılmıştır. Türkçeye Fransızcadan ml, yoksa İngilizceden mi geçtiğini bulabilmek için sözcüğün Fransızcadaki ve İngilizcedeki anlamlarına ve telaffuzlarına bakalım. Le Grand Robert de la langue française'de (= GRLF) Fr. camping için şu yazılmıştır:

\begin{abstract}
'1. Activité touristique qui consiste à vivre en plein air, sous la tente, et à voyager avec le matériel nécessaire (Açlk havada, çadır altında yaşamaktan ve gerekli malzeme ile seyahat etmekten oluşan turistik etkinlik). 2. Un terrain de camping, et, absolt, un camping: terrain où l'on pratique le camping (Kamp alanı ve kamping: Kamp yapılan alan)' (GRLF I, 2001: 1862, 1863).
\end{abstract}

Fransızcada [kãpin] şeklinde telaffuz edilmektedir. İng. camping, Oxford Advanced Learner's Dictionary'de (= Ox) 'living in a tent, etc. on holiday/vacation (Tatilde çadırda vb. yaşama)' (Ox, 2015: 204) şeklinde tanımlanmıştır. Britanya İngilizcesinde ve Amerikan İngilizcesinde telaffuzu ['kæmpın]'dir. Sözcüğün Türkçedeki anlamı ile Fransızcadaki 2. anlamı aynıdır; İngilizcedeki anlam ise daha farklıdır. Türkçedeki yazılış biçimi ile Fransızcadaki ve İngilizcedeki yazılış biçimi aynı değildir. Telaffuzlara bakıldığında Fransızcadakine nazaran İngilizcedeki telaffuz biçiminin Türkçedeki biçime daha yakın olduğu görülmektedir. TS 1944 dâhil önceki sözlüklerde görülmeyen bu sözcük nispeten yeni bir alıntıdır. Bundan dolayı sözcük muhtemelen İngilizceden transfonemizasyonla (İng. /c/ > T. /k/) yazılı yolla Türkçeye geçmiş olmalıdır. Buna göre görüşümüz TS, TAS ve TBKKS ile değil, MS ile uyuşmaktadır.

\title{
Kanyon sözcüğünün kökeni
}

Kanyon sözcüğünün anlamı TS 1944'te 'Bir akar suyun yeri oyarak meydana getirdiği derin, dar ve dolambaçlı boğaz' (TS, 1944: 312), TS'de ve TBKKS'de 'coğ. Bir akarsuyun kalkerli bir alanda oyarak oluşturduğu, bir kıvrımı keserek iki yandaki çukurlukları birleştiren, dar ve boğaz biçimindeki vadi, dar boğaz, kapuz, kısık, klüz' (TS, 2011: 1302; TBKKS, 2015: 633), MS'de 'Tabanında genellikle akarsu bulunan, sarp kayalık yamaçlar arasında meydana gelmiş dar ve derin vâdî [Deniz diplerinde de rastlanan benzeri yapıya deniz kanyonu adı verilir]' (MS, 2011: 1576), TAS'ta 'Bir akarsuyun kalkerli bir alanda oyarak oluşturduğu, bir kıvrımı keserek iki yandaki çukurlukları birleştiren, dar ve boğaz biçimindeki vadi, dar boğaz, kapuz, kısık' (TAS, 2015: 414) şeklinde verilmiştir. Men., Red. ve KT’de geçmemektedir. TS 1944'te İspanyolca, TS ve TAS'ta Fransızca, MS ve TBKKS'de ise İngilizce kökenli olduğu belirtilmiştir. Sözcüğün Türkçeye İspanyolcadan geçmiş olmasının muhtemel olmadığını ifade edebiliriz; İspanyolcadaki kelimenin telaffuzu Türkçedeki biçimle tam olarak uyuşmamaktadır. Türkçeye Fransızcadan mı, yoksa İngilizceden mi geçtiğini saptayalım: GRLF'de Fr. canyon şöyle geçmektedir: 'cañon: Géogr. Gorge ou ravin étroit, profond, sinueux, creusé par un cours d'eau dans une chaîne de montagnes (cañon: coğ. Bir dağ zincirinde bir akarsu tarafindan kazılmış dar, derin, kıvrımlı boğaz veya dağ geçidi)' (GRLF I, 2001: 1884, 1885, 1891). Telaffuzu Fransızcada [kanjõ] ve [kanjon]'dur. İng. canyon, Webster's Encyclopedic Unabridged Dictioanry of the English Language'de $(=\mathrm{Wb})$ şöyle açıklanmıştır: 'a deep valley with steep sides, often with a stream flowing through it. Also, cañon (Dik kenarları olan derin bir vadi, genellikle arasından akan bir dere ile. Ayrıca, cañon)' (Wb, 1996: 306, 307). Britanya İngilizcesinde ve Amerikan İngilizcesinde telaffuzu ['kænjən]'dır. Sözcüğün Türkçedeki anlamıyla Fransızcadaki ve İngilizcedeki anlamının aynı olduğu görülmektedir. Fransızcadaki, İngilizcedeki yazılış biçimi ve İngilizcedeki telaffuz biçimi Türkçedekinden farklıdır. Fransızcadaki telaffuz biçimi ise Türkçedekiyle aynıdır. Sözcüğün TS 1944’te dahi bulunması nispeten yeni bir alıntı olmadığına işaret etmektedir. Bu da Türkçeye İngilizceden değil, muhtemelen Fransızcadan geçtiğini göstermektedir. Telaffuz biçiminin uyuşması ve nispeten

\footnotetext{
RumeliDE Dil ve Edebiyat Araștırmaları Dergisi Osmanağa Mahallesi, Mürver Ciçeği Sokak, No:14/8 Kadıköy - İSTANBUL / TÜRKIYE 34714 e-posta: editor@rumelide.com tel: +90 505 7958124, +90 2167730616 
yeni bir alıntı olmaması nedenlerinden dolayı sözcük Türkçeye muhtemelen Fransızcadan sözlü yolla geçmiştir. Buna göre MS ve TBKKS ile değil, TS ve TAS ile aynı görüşte olduğumuzu belirtebiliriz.

\section{Kargo sözcüğünün kökeni}

Kargo sözcüğü için TS'de şu yazılıdır:

'1. Yük taşıyan uçak veya gemi. 2. Uçak, gemi vb. bir taşıtla taşınan eşya, yük. 3. Bir yerden bir yere yük veya posta taşıyan şirket. 4. Bu şirketin taşıdığı yük veya posta' (TS, 2011: 1328).

MS'de '1. Gemi, uçak, kamyon vb. araçlarla taşınan eşyâ, yük. 2. Yük taşıma' (MS, 2011: 1600), TAS'ta 'Uçak, gemi gibi bir taşıtla taşınan veya böyle bir taşıta verilen yük, eşya' (TAS, 2015: 419), TBKKS'de '1. Uçak, gemi vb. bir taşıtla taşınan eşya, yük. 2. Bu şirketin taşıdı̆̆ı yük veya posta' (TBKKS, 2015: 651) şeklinde açıklanmıştır. Men., Red., KT ve TS 1944’te görülmemektedir. TS ve TAS’ta Fransızca, MS ve TBKKS'de İngilizce kökenli olduğu ifade edilmiştir. Türkçeye Fransızcadan mı, yoksa İngilizceden mi geçtiğini bulabilmek için sözcüğün Fransızcadaki ve İngilizcedeki anlamlarını ve telaffuzlarını ele alalım. Fr. cargo GRLF'de şöyle açıklanmıştır:

'1. Navire destiné surtout au transport des marchandises (Yük taşımaya tahsis edilmiş gemi). 2. Par appos. Avion-cargo (ekleme Kargo-uçak)' (GRLF I, 2001: 1943).

Fransızcada [kaRgo] şeklinde telaffuz edilmektedir. Wb'de İng. cargo için şu yazılmıştır:

'1. the lading or freight of a ship, airplane, etc. (Bir geminin, uçağın vb. yükü veya eşyası). 2. load (Yük)’ (Wb, 1996: 315).

Telaffuzu Britanya İngilizcesinde ['ka:gəv], Amerikan İngilizcesinde ise ['ka:rgəə]'dur. Sözcüğün Türkçede, Fransızcadaki ve İngilizcedekine kıyasla daha fazla anlamı bulunmaktadır. Türkçedeki 1. anlamıyla Fransızcadaki 1. ve 2. anlamları, Türkçedeki 2. anlamıyla İngilizcedeki 1. anlamı aynıdır. Türkçedeki yazılış biçimiyle Fransızcadaki ve İngilizcedeki yazılış biçimi aynı değildir. Ancak İngilizcedeki telaffuz biçimi Türkçedeki ile bire bir uyuşmasa da Fransızcadaki telaffuz biçiminin Türkçedekiyle uyuştuğu açıktır. Buna istinaden Türkçeye muhtemelen Fransızcadan sözlü yolla geçmiştir. Dolayısıyla MS ve TBKKS ile değil, TS ve TAS ile aynı fikirde olduğumuzu söyleyebiliriz.

\section{Kateter sözcüğünün kökeni}

Kateter sözcüğ̈̈ TS'de ve TBKKS'de 'Teşhis ve tedavi amacıyla vücut boşluklarına, damarlar içine ilaç veya sıvı vermek veya almak için özel olarak hazırlanmış tüp' (TS, 2011: 1349; TBKKS, 2015: 675), şeklinde geçmektedir. Men., Red., KT, TS 1944, MS ve TAS'ta bulunmamaktadır. TS'de Fransızca, TBKKS'de ise İngilizce kökenli gösterilmiştir. Türkçeye Fransızcadan ml, yoksa İngilizceden mi alıntılandığını anlayabilmek için Fransızcadaki ve İngilizcedeki anlamlarına ve telaffuzlarına bakalım: GRLF'de Fr. cathéter'in açıllaması şu şekildedir:

'Méd. Sonde cannelée, creuse ou pleine, servant à explorer ou à dilater un canal, un orifice (tzp Bir kanal, bir deliği incelemeye veya genişletmeye yarayan, yivli, çukur ya da dolu inceleme çubuğu (sonda))' (GRLF I, 2001: 2003).

Wb'de İng. catheter şöyle tanımlanmıştır:

'Med. a flexible or rigid hollow tube employed to drain fluids from body cavities or to distend body passages, esp. one for passing into the bladder through the urethra to draw off urine or into the heart through a leg vein or arm vein for diagnostic examination (tıp Sivıları vücut boşluklarından

\section{Adres $\mid$ Address}

RumeliDE Dil ve Edebiyat Araşttrmaları Dergisi $\quad$ RumeliDE Journal of Language and Literature Studies Osmanağa Mahallesi, Mürver Çiçeği Sokak, No:14/8 Osmanağa Mahallesi, Mürver Çiçeği Sokak, No:14/8

Kadıköy - ISTANBUL / TÜRKIYE 34714 Kadıköy - ISTANBUL / TURKEY 34714 e-posta: editor@rumelide.com

tel: +90 505 7958124, +90 2167730616 phone: +90 505 7958124, +90 2167730616 
boşaltmak veya vücut geçitlerini genişletmek için kullanılan esnek veya sert, içi boş bir tüp, özellikle tanısal inceleme amacıyla üretradan mesaneye geçip idrar çekmek veya bacak damarından ya da kol damarından kalbe geçmek için)' (Wb, 1996: 328).

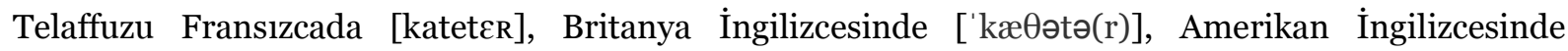
['kæӨətər]'dır. Bir tıp terimi olan bu sözcügün Türkçedeki anlamıyla Fransızcadaki ve İngilizcedeki anlamı uyuşmaktadır. Fransızcadaki ve İngilizcedeki yazılış biçiminin Türkçedekinden farklı olduğu aşikârdır. Öte yandan Türkçedeki telaffuz biçimiyle Fransızcadakinin aynı olduğu, ancak İngilizcedeki telaffuz biçiminin farklı olduğu görülmektedir. TS 1944’te ve önceki sözlüklerde görülmemesi nispeten yeni bir alıntıymış izlenimi verse de sözcüğün Fransızcadaki telaffuz biçiminin Türkçedeki biçimle uyuşması nedeniyle Türkçeye muhtemelen Fransızcadan sözlü yolla geçtiği kanaatindeyiz. Buna göre TBKKS ile değil, TS ile aynı düşündüğümüzü ifade edebiliriz.

\title{
Komodor sözcüğünün kökeni
}

Komodor sözcüğü TS 1944'te 'Amiralden küçük deniz komutanı' (TS, 1944: 357), TS'de ve TAS'ta '1. Amiral yetkisiyle görevli deniz subayı. 2. Bir kuruluşa bağlı yolcu gemilerinin en eski kaptanı' (TS, 2011: 1467, 1468; TAS, 2015: 448), MS'de '1. Amiral yetkisine sâhip deniz subayı. 2. Bir kuruluşa bağlı yolcu gemilerinin en eski kaptanı' (MS, 2011: 1757), TBKKS'de 'Amiral yetkisiyle görevli deniz subayı' (TBKKS, 2015: 737) anlamlarıla görülmektedir. Men., Red. ve KT’de yoktur. TS 1944, MS ve TBKKS'de İngilizce, TS ve TAS’ta ise Fransızca kökenli olarak yer almaktadır. Türkçeye İngilizceden mi, yoksa Fransızcadan mı geçtiğini ele alalım: Wb'de İng. commodore için şu yazılmıştır:

\begin{abstract}
'1. Navy. a grade of flag officer next in rank below a rear admiral (donanma Rütbede bir arka amiralin altındaki bir dereceli amiral). 2. Brit. Navy. an officer in temporary command of a squadron, sometimes over a captain on the same ship (İng. donanma Bir filonun geçici olarak komutasındaki bir subay, bazen aynı gemideki bir kaptanın üzerinde). 3. Navy. the senior captain when two or more ships of war are cruising in company (donanma İki veya daha fazla savaş gemisi birlikte seyir hâlindeyken kıdemli kaptan). 4. (in the U.S. Navy and Merchant Marine) the officer in command of a convoy ((ABD donanması ve ticaret gemisinde) Bir konvoyu komuta eden subay). 5 . the senior captain of a line of merchant vessels (Bir ticaret gemisi hattının kıdemli kaptanı). 6. the president or head of a yacht club or boat club (Bir yat kulübü veya tekne kulübünün başkanı ya da yöneticisi)' (Wb, 1996: 412).
\end{abstract}

Sözcüğün Türkçedeki anlamlarıyla İngilizcedeki 1., 2., 3. ve 5. anlamları uyuşmaktadır. Britanya İngilizcesinde ['kbmədo:(r)], Amerikan İngilizcesinde ['ka:mədo:r] şeklinde telaffuz edilmektedir. GRLF'de Fr. commodore 'Dans les marines de guerre britannique, américaine et néerlandaise, officier qui vient immédiatement au-dessous du contre-amiral (İngiliz, Amerikan ve Hollanda savaş gemilerinde tuğamiralin hemen alt rütbesinde olan subay)' (GRLF II, 2001: 328) şeklinde açıklanmıştır. Telaffuzu Fransızcada [komodor] şeklindedir. Sözcük Türkçede Fransızcadakinden daha fazla anlama sahiptir. Genel olarak bakıldığında Türkçedeki 'Amiral yetkisiyle görevli deniz subayı' anlamıyla Fransızcadaki anlamın örtüştüğü görülmektedir. İngilizcedeki yazılış biçimi ile Fransızcadaki yazılış biçiminin aynı olduğu, fakat bunun Türkçedekinden farklı olduğu anlaşılmaktadır. Telaffuz biçimine bakıldığında ise sözcüğün İngilizcede Türkçedekinden farklı telaffuz edildiği, ancak Fransızcadaki telaffuz biçimiyle Türkçedekinin aynı olduğu söylenebilir. Nitekim TS 1944'te de yer aldığından nispeten yeni bir alıntı sayılmaz; bu durum da sözcügün Türkçeye İngilizceden değil de Fransızcadan geçmiş olma olasılı̆̆ını artırmaktadır. Bundan dolayı sözcüğün Türkçeye muhtemelen Fransızcadan sözlü yolla geçmiş olabileceğini dile getirebiliriz. Buna göre sözcük TS 1944, MS ve TBKKS'de yazıldığı gibi İngilizce kökenli değil, TS ve TAS’ta yazıldığı gibi Fransızca kökenlidir.

RumeliDE Dil ve Edebiyat Araştırmaları Dergisi Osmanağa Mahallesi, Mürver Ciçeği Sokak, No:14/8 Kadıköy - ISTANBUL / TÜRKIYE 34714 e-posta: editor@rumelide.com tel: +90 505 7958124, +90 2167730616
Address

RumeliDE Journal of Language and Literature Studies Osmanağa Mahallesi, Mürver Çiçeği Sokak, No:14/8

Kadıköy - ISTANBUL / TURKEY 34714

e-mail: editor@rumelide.com

phone: +90 5057958124 , +90 2167730616 


\section{Kompleks sözcüğünün kökeni}

Kompleks sözcüğü için TS'de şu yazılmıştır:

'1. Karmaşık. 2. Vitamin veya proteinlerin oluşturduğu bileşik. 3. kim. Karmaşık. 4. Karmaşıklık, karmaşa. 5. Aynı ekonomik etkinliği gerçekleştiren sanayinin tesisler bütünü, kuruluşlar bütünü. 6 . ruh b. Karmaşa' (TS, 2011: 1468).

Bu sözcüğün MS'deki açıklaması şöyledir:

'1. Karmaşık, anlaşılması güç olan. 2. psiko. Toplumla çatışmaya sebep olacağı için kişi tarafından bastırılıp şuur altına itilen, tatmin edilmemiş istek ve arzular. 3. Aynı malı üreten, aynı işi yapan ve bir arada bulunan kuruluşların tamâmı, tesis. 4. mimar. Külliye, manzûme' (MS, 2011: 1758).

TAS’ta şu şekilde anlamlandırılmıştır:

'1. Karmaşık. 2. Vitamin veya proteinlerin oluşturduğu bileşik. 3. Karmaşık. 4. Karmaşıklık, karmaşa. 5. Aynı ekonomik etkinliği gerçekleştiren sanayinin tesisler bütünü, kuruluşlar bütünü. 6 . Karmaşa' (TAS, 2015: 448).

TBKKS'de aşağıdaki gibi tanımlanmıştır:

'1. Karmaşık. 2. Vitamin veya proteinlerin oluşturduğu bileşik. 3. Karmaşıklık, karmaşa. 4. Aynı ekonomik etkinliği gerçekleştiren sanayinin tesisler bütünü. 5. Ruhsal karmaşa' (TBKKS, 2015: 739, 740).

Men., Red., KT ve TS 1944'te geçmemektedir. TS, MS, TAS ve TBKKS'de Fransızca kökenli olarak yazılmıştır. Ancak TS 1944 ve önceki sözlüklerde bulunmayan bu sözcüğün nispeten yeni bir alıntı olması akla geldiğinden sözcüğün Türkçeye İngilizceden geçmiş olma olasılığı üzerinde durmak gerekmektedir. Sözcüğün Türkçeye Fransızcadan mı, yoksa İngilizceden mi geçtiğini saptayabilmek için Fransızcadaki ve İngilizcedeki anlamlarını ve telaffuzlarını gösterelim: GRLF'de Fr. complexe şöyle açılanmıştır:

'I. Adj. (sf.) 1. Qui contient, qui réunit plusieurs éléments différents (Farklı birçok unsuru içeren, birleştiren). 2. Cour. Difficile, à cause de sa complication (çoğunlukla Karmaşıklı̆̆ından dolayı zor olan). II. N. m. (is. eril) 1. Physiol. Association de plusieurs phénomènes ou substances formant une entité ou concourant à une activité bien définie (fizy. Birçok görünüm veya maddenin birleşmesinden oluşan varlık ya da tanımlı bir etkiye ulaşma durumu). 2. Pathol. Ensemble de plusieurs lésions ou anomalies (patol. Birçok doku bozukluğu veya anomalinin birleşimi). 3. Psychol. (psikol.) a. Ensemble perçu globalement, sans analyse de ses parties composantes (Bileşenlerin incelenmeden bir bütün olarak algılanması). b. Psychan. Ensemble des traits personnels acquis dans l'enfance, doués d'une puissance affective et généralement inconscients, chez un individu (psikan. Kişide çocukluğunda duygusal güç içeren ve genellikle bilinç dışı oluşan kişisel özelliklerin bütünü). c. Cour. et fam. Sentiment (d'infériorité) ou angoisse, etc., auquel on attribue tout comportement inhibé, obsessif (çoğunlukla ve sık kullanım şekli Engellenmiş veya takıntılı her tür davranışa atfedilen duygu (aşağılık) veya ıstırap). 4. Chim. Molécule (ou ion) dans laquelle un atome central est lié à d'autres atomes ou groupes d'atomes en nombre supérieur à la charge ou au degré d'oxydation de l'atome central. Edifice formé d'ions ou de molécules venus se lier chimiquement soit à un atome isolé neutre ou ionisé, soit à un atome situé en position centrale d'une molécule, augmentant ainsi le nombre de liaisons issues de cet atome (kim. Merkezî atomdan daha fazla yüklü veya oksidasyon derecesi daha yüksek birçok atoma veya atom grubuna bağlı merkezî atomdan oluşan molekül (veya iyon). İyon veya moleküllerin ayrılmış, bağımsız veya iyonize olmuş bir atoma veya molekülün merkezindeki bir atoma kimyasal olarak birleşmesiyle bu atomun bağlantılarını çoğaltarak oluşan yapı). 5. Math. Se dit de certains ensembles (de courbes, etc.) (mat. Bazı bileşimlere verilen ad (eğriler vb.)). 6. Écon. Ensemble d'industries qui concourent à une même production. Construction formée de nombreux élements coordonnés (ekon. Aynı üretime yönelmiş sanayi grupları. Yapıtaşların eşgüdümlü birleşiminden oluşan yapı). 7. Par. plais.

\footnotetext{
Adres
RumeliDE Dil ve Edebiyat Araştırmaları Dergisi Osmană̆a Mahallesi, Mürver Ciçeği Sokak, No:14/8 Kadıköy - İSTANBUL / TÜRKIYE 34714 e-posta: editor@rumelide.com

Address

RumeliDE Journal of Language and Literature Studies Osmanağa Mahallesi, Mürver Çiçeği Sokak, No:14/8

Kadıköy - ISTANBUL / TURKEY 34714

e-mail: editor@rumelide.com,

tel: +90 505 7958124, +90 2167730616 phone: +90 505 7958124, +90 2167730616
} 
Ensemble concret plus ou moins compliqué (şakadan Az veya çok karmaşıktan oluşan somut bileşen)' (GRLF II, 2001: 357, 358).

Telaffuzu Fransızcada [kว̃pleks] şeklindedir. Sözcüğün Türkçedeki TS’deki ve TAS’taki 3. anlamıyla Fransızcadaki 4. anlamının ve Türkçedeki TS'deki, TAS'taki 5., MS'deki 3. ve TBKKS'deki 4. anlamıyla Fransızcadaki 6. anlamının uyuştuğu ifade edilebilir. Sözcüğün Fransızcadaki telaffuz biçimi, Türkçedeki telaffuz biçimiyle aynıdır. Yazılış biçimlerine bakıldığında Fransızcadakine nazaran İngilizcedeki yazılış biçiminin Türkçedekine daha çok uyduğu görülmektedir. Wb’de İng. complex şöyle geçmektedir:

\begin{abstract}
'- adj. (sf.) 1. composed of many interconnected parts; compound; composite (Birbirine bağll birçok parçadan oluşan; bileşik; karışı). 2. characterized by a very complicated or involved arrangement of parts, units, etc. (Parçaların, birimlerin vb. çok karmaşık veya girift bir şekilde düzenlenmesi ile karakterize edilen). 3. so complicated or intricate as to be hard to understand or deal with (Anlaması veya başa çıkması zor olacak kadar karışık veya karmaşık). 4. Gram. (dil bilgisi) a. (of a word) consisting of two parts, at least one of which is a bound form, as childish, which consists of the word child and the bound form -ish ((bir kelime ile ilgili) En az biri bağımlı olmak üzere iki parçadan oluşan, çocuk kelimesinden ve bağımlı biçim olan -ça'dan oluşan çocukça gibi). b. complex sentence: a sentence containing one or more dependent clauses in addition to the main clause (Bileşik cümle: Ana cümleye ek olarak bir veya daha fazla bağımlı cümle içeren bir cümle). 5. Math. pertaining to or using complex numbers (mat. Karmaşık sayılarla ilgili veya karmaşık sayıları kullanan). $-n$. (is.) 6. an intricate or complicated association or assemblage of related things, parts, units, etc. (İlgili şeylerin, parçaların, birimlerin vb. girift veya karmaşı bir şekilde ilişkilendirilmesi veya toplanması). 7. Psychol. a system of interrelated, emotion-charged ideas, feelings, memories, and impulses that is usually repressed and that gives rise to abnormal or pathological behavior ( $p$ sikol. Genellikle bastırılan ve anormal veya patolojik davranışlara yol açan birbiriyle ilişkili, duygu yüklü fikirler, hisler, anılar ve dürtüler sistemi). 8. a fixed idea; an obsessive notion (Sabit bir fikir; saplantılı bir düşünce). 9. Math. (mat.) a. an arbitrary set of elements of a group (Bir grubun seçmeli bir küme elemanı). b. a collection of simplexes having specified properties (Belirlenmiş özelliklere sahip bir simpleks koleksiyonu). 10. Also called coordination compound. Chem. a compound in which independently existing molecules or ions of a nonmetal form coordinate bonds with a metal atom or ion (Coordination compound olarak da adlandırllır. kim. Bir ametalin bağımsız olarak var olan moleküllerinin veya iyonlarının bir metal atomu veya iyonu ile koordinat bağları oluşturduğu bir bileşik). 11. Biochem. an entity composed of molecules in which the constituents maintain much of their chemical identity (biyokim. Bileşenlerin kimyasal kimliklerinin çoğunu korudukları moleküllerden oluşan bir oluşum)' (Wb, 1996: 419).
\end{abstract}

Britanya İngilizcesinde ['kbmpleks], Amerikan İngilizcesinde [kəm'pleks] ve ['ka:mpleks] şeklinde telaffuz edilmektedir. Sözcügün Türkçedeki TS, MS, TAS ve TBKKS'deki 1. anlamıyla İngilizcedeki 3. anlamının, MS'deki 2. anlamıyla İngilizcedeki 7. anlamının örtüştüğü anlaşllmaktadır. Türkçedeki telaffuz biçimi, Britanya İngilizcesindekiyle aynıdır. Nispeten yeni bir alıntı olması, yazılış biçiminin ve telaffuz biçiminin Türkçedeki biçimle Fransızcadakine nazaran daha çok uyuşması nedenleriyle sözcüğün Türkçeye muhtemelen Britanya İngilizcesinden sözlü yolla alıntılanmış olabileceğini düşünmekteyiz. Buna göre sözcük TS, MS, TAS ve TBKKS'de belirtildiği gibi Fransızca değil, İngilizce kökenli olmalıdır.

\title{
Konteyner sözcüğünün kökeni
}

Konteyner sözcüğü TS'de 'tic. Taşımalık' (TS, 2011: 1474), MS'de 'Özellikle deniz taşımacilı̆̆ında yükleme boşaltmayı hızlandırmak ve malların muhâfazalı bir şekilde naklini sağlamak için kullanılan, genellikle demirden, büyük ebatlı sandık, kap, kutu vb.' (MS, 2011: 1764), TAS'ta 'Taşımalık, bozulabilecek malların ülkeden ülkeye veya kentten kente taşınmasında kullanılan, çelik, alüminyum vb.den yapılmış, kilitlenip mühürlenebilen kapakla donatılmış büyük kap' (TAS, 2015: 454), TBKKS'de 'Çeşitli eşyaları taşımak için uluslararası standartlara göre tahtadan veya metalden yapılmış büyük kasa, taşımalık ' (TBKKS, 2015: 768) olarak tanımlanmıştır. Men., Red., KT ve TS 1944’te 
bulunmamaktadır. TS, TAS ve TBKKS'de Fransızca, MS'de ise İngilizce kökenli olduğu ifade edilmiştir. Türkçeye Fransızcadan mı, yoksa İngilizceden mi geçtiğini kavrayabilmek gerekmektedir. Bu nedenle sözcüğün Fransızcadaki ve İngilizcedeki anlamlarına ve telaffuzlarına bakalım: GRLF'de Fr. container 'Anglic. Caisse pour le transport de marchandises (İng. Eşya taşımak için kutu)' (GRLF II, 2001: 502) olarak açıklanmıştır. Fransızcada [kõtєnœe] şeklinde telaffuz edilmektedir. Sözcüğün Türkçedeki anlamıyla Fransızcadaki anlamı uyuşmaktadır. Fransızcadaki yazılış biçimi ve telaffuz biçimi ise Türkçedekinden farklıdır. Wb'de İng. container'ın anlamı şu şekilde verilmiştir:

\begin{abstract}
'1. anything that contains or can contain something, as a carton, box, crate, or can (Bir şey içeren ya da içerebilecek herhangi bir şey; karton, kutu, sandık veya teneke kutu gibi). 2. a large, vanlike, reusable box for consolidating smaller crates or cartons into a single shipment, designed for easy and fast loading and unloading of freight (Yüklerin kolay ve hızlı yüklenmesi ve boşaltılması için tasarlanmış, küçük kasaları veya kartonları tek bir sevkiyatta birleştirmeye yönelik büyük, yük vagonu benzeri, yeniden kullanilabilir bir kutu)' (Wb, 1996: 438).
\end{abstract}

Britanya İngilizcesinde [kən'teInə(r)], Amerikan İngilizcesinde [kən'teInər] şeklinde telaffuz edilmektedir. Sözcük Türkçede İngilizcedeki 2. anlamılla kullanılmaktadır. Türkçedeki yazılış biçimi ile İngilizcedeki aynı değildir; ancak Türkçedeki telaffuz biçimi ile Amerikan İngilizcesindeki telaffuz biçimi uyuşmaktadır. Bu biçimle TBKKS'de geçen konteyner haricindeki konteynır şeklindeki yazılış/telaffuz benzeşmektedir (TBKKS, 2015: 768). Sözcüğün TS 1944'te dahi yer almamasından nispeten yeni bir alıntı olduğu söylenebilir. Hem yeni bir alıntı oluşu hem de telaffuz biçimi nedeniyle sözcüğün Türkçeye muhtemelen İngilizceden sözlü yolla geçmiş olduğunu ifade edebiliriz. Buna göre görüşümüz TS, TAS ve TBKKS ile değil, MS ile uyumludur.

\title{
Kovboy sözcüğünün kökeni
}

Kovboy sözcügü TS 1944'te 'Amerikada sığır çobanlarına verilen ad' (TS, 1944: 362), TS'de '1. Amerika'da sığır çobanı. 2. mec. Gangsterliğe özenen kimse' (TS, 2011: 1490), MS'de '1. Amerika'da sığır çobanlarına verilen isim. 2. Amerikan filimlerinde at ve silâh kullanmakta mâhir, bâzan insanlara zulmeden, bâzan hakları koruyan bir tip' (MS, 2011: 1778), TAS’ta ve TBKKS'de '1. Amerika'da sığır çobanlarına verilen ad. 2. Amerikanvari gangsterlik taslayan kimse' (TAS, 2015: 460; TBKKS, 2015: 792) anlamlarıyla verilmiştir. Men., Red. ve KT'de yoktur. TS 1944, MS, TAS ve TBKKS'de İngilizce kökenli olduğu belirtilmiştir, TS'de ise Fransızca kökenli olarak geçmektedir. Anlamlardan ve telaffuzlardan yola çıkarak sözcügün Türkçeye İngilizceden mi, yoksa Fransızcadan mı geçtiğini çözmeye çalışalım. Wb’de İng. cowboy aşağıdaki gibi anlamlandırılmıştır:

\begin{abstract}
'1. a man who herds and tends cattle on a ranch, esp. in the western U.S., and who traditionally goes about most of his work on horseback (Özellikle Batı ABD'de, bir çiftlikte sığırları güdüp bakan ve geleneksel olarak çalışmalarının çoğunu at sırtında yapan bir adam). 2. a man who exhibits the skills attributed to such cowboys, esp. in rodeos (Bu tür kovboylara atfedilen becerileri sergileyen bir adam, özellikle rodeolarda). 3. Chiefly Northeastern U.S. a reckless or speedy automobile driver (başlıca Kuzeydoğu $A B D$ Pervasız veya hızl bir otomobil sürücüsü). 4. Informal. a reckless or irresponsible person, esp. a show-off or one who undertakes a dangerous or sensitive task heedlessly (konuş. $d$. Pervasız veya sorumsuz bir kişi, özellikle gösteriş yapan ya da tehlikeli veya hassas bir görevi dikkatsizce üstlenen kişi). 5. (during the American Revolution) a member of a proBritish guerrilla band that operated between the American and British lines near New York City ((Amerikan devrimi sırasında) New York City yakınlarında Amerikan ve İngiliz hatları arasında faaliyet gösteren İngiliz yanlısı bir gerilla grubunun üyesi)' (Wb, 1996: 467).
\end{abstract}

GRLF'de Fr. cow-boy'un tanımı şöyle yapılmıştır:

'1. Gardien de troupeau de bovins (et, par ext. de chevaux), dans l'ouest des États-Unis (ABD'nin batısında sığır sürüsü çobanı (ve ek olarak atlar)). 2. Cour. Personnage essentiel de la légende de

Adres
RumeliDE Dil ve Edebiyat Araşttrmaları Dergisi Osmanağa Mahallesi, Mürver Ciçeği Sokak, No:14/8 Kadıköy - İSTANBUL / TÜRKIYE 34714 e-posta: editor@rumelide.com tel: +90 $5057958124,+902167730616$
Address

RumeliDE Journal of Language and Literature Studies

Osmanağa Mahallesi, Mürver Çiçeği Sokak, No:14/8

Kadıköy - ISTANBUL / TURKEY 34714

e-mail: editor@rumelide.com,

phone: +90 505 7958124, +90 2167730616 
l'Ouest américain, popularisé par le cinéma (çoğunlukla Batı Amerika'nın sinema tarafından halka sevdirilmiş efsane şahsiyeti)' (GRLF II, 2001: 754).

Telaffuzu Britanya İngilizcesinde ve Amerikan İngilizcesinde ['kavbor], Fransizcada [kawboj] ve [koboj]'dur. Türkçedeki mecaz anlam dışındaki anlamlarla İngilizcedeki, Fransızcadaki 1. ve 2. anlamlar uyuşmaktadır. İngilizcedeki ve Fransızcadaki yazılış biçimi birbirinin aynıdır; ancak bu biçim Türkçedekinden farklıdır. Telaffuzlarına bakıldığında ise Türkçedeki telaffuzun İngilizcedekine Fransızcadaki telaffuzdan daha yakın olduğu görülmektedir. Sözcüğün TS 1944’te bulunması Türkçeye Fransızcadan geçtiği izlenimini verse de Türkçedeki sözcüğün ilk hecesindeki $o$ uzun olduğundan, daha ziyade İngilizcedeki biçim ile uyuşuyor gözükmektedir. İngilizce sözcügün ilk hecesindeki diftong (İng. [aひ] $\rightarrow$ T. /o/ [o:]) Türkçeye ses karşlamasıyla uzun ünlü olarak alıntılanmıştır. Türkçedeki telaffuz biçiminin Fransızcadaki ile değil de İngilizcedekiyle uyuşması nedeniyle sözcüğün Türkçeye muhtemelen İngilizceden sözlü yolla geçmiş olabileceğini düşünebiliriz. Buna göre sözcük TS'de ifade edildiği gibi Fransızca kökenli değil, TS 1944, MS, TAS ve TBKKS'de yazıldığı gibi İngilizce kökenli olmalıdır.

\section{Sonuç}

Bu çalışmada incelenen kamping, kanyon, kargo, kateter, komodor, kompleks, konteyner ve kovboy sözcüklerinin taranan her sözlükte yer almadı̆̆ı, bulundukları sözlüklerin ise bu sözcüklerin kökenleri ile ilgili olarak bazen aynı görüşte oldukları, bazen de ayrı görüş belirttikleri gözlenmiştir. Tarihî, ses bilimsel ve anlam bilimsel veriler ışı̆̆ında adı geçen sözcüklerin kökeninin doğru saptanmasına çalışılmıştır. Varılan sonuçlar kimi zaman taranan bir kısım sözlükteki ifadelerle uyumlu, kimi zaman da diğer bir kısım sözlükte yer alan ifadelerden farklı olmuştur. Buna göre şunu söyleyebiliriz: 1) TS, TAS ve TBKKS'de Fransizca, MS'de ise İngilizce kökenli olduğu belirtilen kamping sözcügü Türkçeye muhtemelen İngilizceden geçmiştir. 2) TS 1944'te İspanyolca, TS ve TAS'ta Fransızca, MS ve TBKKS'de ise İngilizce kökenli olarak yazılan kanyon sözcüğ̈ Türkçeye muhtemelen Fransızcadan geçmiştir. 3) TS ve TAS'ta Fransızca, MS ve TBKKS'de İngilizce kökenli olduğu ifade edilen kargo sözcüğü Türkçeye muhtemelen Fransızcadan alıntılanmıştır. 4) TS'de Fransızca, TBKKS'de ise İngilizce kökenli gösterilmiş olan kateter sözcügü Türkçeye muhtemelen Fransızcadan alınmıştır. 5) TS 1944, MS ve TBKKS'de İngilizce, TS ve TAS'ta ise Fransızca kökenli olarak yer alan komodor sözcüğü Türkçeye muhtemelen Fransızcadan geçmiştir. 6) TS, MS, TAS ve TBKKS'de Fransızca kökenli olarak belirtilmiş olan kompleks sözcügü Türkçeye muhtemelen İngilizceden geçmiştir. 7) TS, TAS ve TBKKS'de Fransızca, MS'de ise İngilizce kökenli olduğu ifade edilen konteyner sözcüğü Türkçeye muhtemelen İngilizceden alınmıştır. 8) TS 1944, MS, TAS ve TBKKS'de İngilizce, TS'de ise Fransızca kökenli olarak geçen kovboy sözcüğü Türkçeye muhtemelen İngilizceden alıntılanmıştır.

\section{Kisaltmalar}

GRLF : Le Grand Robert de la langue française

KT : Kâmûs-ı Türkî

Men. : Thesaurus Linguarum Orientalium Turcicae-Arabicae-Persicae: Lexicon Turcico-ArabicoPersicum

MS : Misalli Büyük Türkçe Sözlük

Ox : Oxford Advanced Learner's Dictionary

Red. : A Turkish and English Lexicon: shewing in English the significations of the Turkish terms

TAS : Türkçenin Alıntılar Sözlüğü

\begin{tabular}{|c|c|}
\hline & \\
\hline aları $D$ & d Literatur \\
\hline $\mathrm{Mal}$ & Mahallesi, Mürver Çiçeği Sokak, No:14/8 \\
\hline Kadıköy & STANBUL / TURKEY 34714 \\
\hline $\begin{array}{r}\text { e-posta: edito } \\
\text { tel: }+905057958124,+\end{array}$ & $\begin{array}{l}\text { editor@rumelide.com, } \\
\text { +90 505 7958124, +90 } 216773 \text { o } 616\end{array}$ \\
\hline
\end{tabular}


TBKKS: Türkçede Batı Kökenli Kelimeler Sözlüğü

TS : Türkçe Sözlük

$\mathrm{Wb} \quad$ : Webster's Encyclopedic Unabridged Dictionary of the English Language

\section{Kaynakça}

Ayverdi, İ. (2011). Misalli büyük Türkçe sözlük. İstanbul: Kubbealtı.

Hornby, A. S. (2015). Oxford advanced learner's dictionary. Oxford: Oxford University.

Karaağaç, G. (2015). Türkçenin alıntılar sözlüğü. Ankara: Akçă̆.

Meninski, F. (2000). Thesaurus linguarum orientalium Turcicae-Arabicae-Persicae: Lexicon Turcico-Arabico-Persicum (haz. Mehmet Ölmez). İstanbul: Simurg.

Redhouse, J. W. (1987). A Turkish and English lexicon: shewing in English the significations of the Turkish terms. Beirut: Librairie du Liban.

Robert, P. (2001). Le grand Robert de la langue française. Paris: Dictionnaires Le Robert.

Saraç, T. (2003). Büyük Fransızca-Türkçe sözlük: Grand dictionnaire Français-Turc. İstanbul: Adam.

Şemseddin Sâmi. (2002). Kâmûs-ı Türkî. İstanbul: Çağrı.

Türkçe sözlük. (1944). İstanbul: Cumhuriyet.

Türkçe sözlük. (2011). Ankara: Türk Dil Kurumu.

Türkçede Batı kökenli kelimeler sözlüğü. (2015). Ankara: Türk Dil Kurumu.

Webster, N. (1996). Webster's encyclopedic unabridged dictionary of the English language. New York: Random House Value.

RumeliDE Dil ve Edebiyat Araştırmaları Dergisi Osmanağa Mahallesi, Mürver Çiçeği Sokak, No:14/8 Kadıköy - İSTANBUL / TÜRKIYE 34714 e-posta: editor@rumelide.com tel: +90 505 7958124, +90 2167730616
Address

RumeliDE Journal of Language and Literature Studies Osmanağa Mahallesi, Mürver Çiçeği Sokak, No:14/8

Kadıköy - ISTANBUL / TURKEY 34714

e-mail: editor@rumelide.com,

phone: +90 505 7958124, +90 2167730616 